\title{
The Design Of Situational Teaching Method In English Vocabulary Teaching
}

\author{
WANG Ruiyang \\ College of Foreign Languages \\ Nanjing Normal University \\ Nanjing, Jiangsu Province, 210023 China
}

\begin{abstract}
This study attempts to explore the effectiveness of english vocabulary situational teaching method by observing and analyzing the situation to two classes of English vocabulary teaching comparative experiments.Firstly, this article defined the research purpose, and then describes the research method, and finally focused on the experimental process.Results of this study will play a useful reference for the optimization of english vocabulary teaching.
\end{abstract}

Keywords- situational teaching meth situational teaching methodod; English vocabulary; teaching design

\section{EXPERIMENT DESIGN}

Experiment design of this study include the following aspects.

Research questions:The effectiveness and feasibility of situationalapproach in teaching English vocabulary.

Research hypothesis:In high school English vocabulary teaching, using situational approach is more effective than general vocabulary teaching, students can better accept and grasp vocabularEnglish .

Experimental treatment:Group one:class 1 is experimental class.Basically use situational teaching method to teach English vocabulary, that is, the vocabulary is put into different teaching contexts as much as possible.Group two:Classe 2 is the comparison class, using conventional vocabulary teaching mode, that is, the preparation is according to the teaching outline, teaching materials, teaching reference. Most are learning a new word list and unit before the start learning of a word.

The dependent variable measured: twice final grade.

Controlled conditions:The same teaching; Unified teaching content and class schedule; Before the start of the experiment;Before the experiment began, two classes final test during a semester scores are pretest;After the end of the experiment, two classes final test results are the posttest.

Experimental design: Unequal control group design.

\section{EFFECTIVELY TO IMPLEMENT SITUATIONAL VOCABULARY TEACHINGIN LISTENING, SPEAKING, READING AND WRITING}

\section{A. Create situations for vocabulary teaching in the teaching of listening}

In listening teaching activities, teachers can hollowe out investigated vocabulary or word blocks to allow students to fill in the blank, the content can be brief sentence or a paragraph.

For example, Reading A Trip On "The True North" of Unit 5 Canada-“TheTrue North", Book 3, NSEFC,at the end of reading the first lesson, the teacher can fill in the blank mesh designed listening practice vocabulary.

The design filling in the blank as follows:

(1) Canada is a _____ of many cultures and races. (mixture)

(2) _____ take a plane, they decided to fly to Vancouver and then take the train west toeast across Canada. (Rather than)

(3) Earlier that day, when they crossed the Rockey Mountains, they ________ catch sight of some mountain goats and even a grizzly bear and an eagle. (managed to) .

The answer in the in brackets is an important lesson vocabulary through listening exercises, getting practice to enhance memory.

An extracurricular reading about introducing U.S. and Chinese articles, after students read the text, teachers can design follows chunks dictation practice according to the article.

Hearing fragment 1:

We have one of 1 in the world protecting the rights of everyone in our country, and many people come to see our famous statue which represents 2 . But our country still isn't perfect and we do have a lot of crime like many other places in the world today.

Listening fragment 2 :

3 the population of many country is so large ---we are one of the largest countries in the world! 4 more than 5000 years and touris ts 5 see sights through the country.

(Reference answer: 1:the most famous constitutions 2:freedom and liberty 3:It's not surprising that 4:Our history goes back 5:are always thrilled to) 
There are are numerous vocabulary situational teaching method in English listening teaching,for example, let the students conduct note-taking in the hearing process, and it is an abstract vocabulary and reinforcing process; teachers may allow students to use some key vocabulary or writing after repeated listening activities, so they let the students practice vocabulary deeper to master the lesson.

\section{B. Create situations for vocabulary teaching in the teaching of speaking}

In the classroom import, teachers can create teaching vocabulary to speaking situations.For example, in Reading Satisfaction Guaranteed of Book 7,teachers import situational vocabulary teaching: in the following ways:Teachers. Importing a JJ pop "NO. 89757" about robots, in which the lyrics are translated as follows:I will finish the house-cleaning in 10 minutes. I will____(accompany) you , when you are alone.Generally speaking,accompany is a new word,teachers can also give the phrase "keep accompany with". Then the teacher let the students discuss and give sentence:Oh, my god! It's to have a robot like this falling in love with me.Students will be able to as sociate the phases and words:terrible/e mbarras singawful; ridiculous/unreasonable-absurd; or disturbing/frightening-alarming.In this way, students will be able to think of many adjectives to describe. Teachers then took the opportunity to summarize some of the synonyms.

Then, in the post-reading section. Teachers can also create such a speaking situation:

Let's make a phone call!A call from Gladys:(AGladys;B-Clarie)

A:Hello,Clarie. It's Gladys. Thank you for the party last night. It's amazing.

Especially Tony. Well,er,are you having an affair?

$\mathrm{B}:$ No,no! Tony is only a

A:Oh, my god! It's ____ ! Do you like him at the first sight?

B:Not exactly! At the beginning,......

A:All in all,are you satis fied with "it"?

B:.......

Through this scenario drills, students not only consolidate some vocabulary but also grasp the main idea to achieve the effect of active outputs. Of course, there are many other speaking teaching, vocabulary teaching methods to create situations, for example, to build the Semantic Web by brainstormingactivities:When said part of the body, we can spread the word about some of the body parts; or give the same Chinese word can find out a lot about this English expression meaning; Through a large series of the word first and the end,forexample greenhouse-housework-workdaydaytime-timetable-tabletennis;Teachers can give students to retell some keywords or give some words for students to make up stories; may also allow students to apply what they have learned term or just learn to do interpreting practice.Among these, teachers should pay attention to the selected sentence should be practical, as close to life, with a sense of the times, so that students can be off now.For example, potential, for students to translate the word:In China,the Ministry of Education has encouraged schools to provide quality education to tap students' potential. "hit" is a relatively large number of word usage, ask students to discuss "hawking fever" hits China" or "Tennis princess is a big hit in China"and other interested topic,Sort of vocabulary teaching methods can be carried out in speakin drills activities. This can enable the communicative activities in the classroom, active classroom atmosphere,while allowing vocabulary teaching with authenticity and practical significance, the most important thing is to allow students to become interested in learning vocabulary and the effect is obvious.

\section{Create situations for vocabulary teaching in the teaching of reading}

In skimming part, teachers can allow students to do the vocabulary fill in the blank, and point out new vocabulary to grasp the effect of the article.

The text is mainly about how a (household) robot was _____(tested out) in a family.

Words in brackets as a new term, students through such an answer can deepen the impression of the word, and it is much more effective than the teachers tell students the meaning of the word Then, in perusing this article, some teachers may create situations:

Question: How did Clarie feel about Tony? Why?

Teacher can then set questions from the students' answer. At the beginning:

alarmed/ alarming

(Teacher can expand the vocabulary:I feel alarmed./ It is alarming)

embarras sed/ embarrassing

(Teacher can expand the vocabulary:I feel embarrassed./ It is embarrassing)

disturbing/ disturbed

(Teacher can expand the vocabulary:I feel disturbed./ It is disturbing)

before the party: frightened/ frightening

(Teacher can expand the vocabulary: I feel frightened./ It is frightening)

amazed/ amazing

(Teacher can expand the vocabulary:I feel amazed./ It is amazing)

In the teaching of reading, there are a lot of vocabulary teaching situation. As in understanding the meaning of a new word or phrase, the teacher can show a different sense of the word in different sentences, allow students to choose the same meaning as in the text containing the word meaning sentence. In this way, they can understand the words but also the other meaning of this term. To expand. Try presented in the context of vocabulary, learn vocabulary in context, and allow students to learn how to learn vocabulary in context.

\section{Create situations for vocabulary teaching in the teaching of writing}

Here we are not referring to mechanically copying the text or phrase,but do some sentences translated around vocabulary or read texts and materials, according to the keywords provided by the abbreviation, rewritten, or comb ine text articles exported a topic for students to consolidate 
vocabulary in practice writing, in writing exercises, teachers can remind students to pay attention to some transitional vocabulary used in the pre-write,such as "first of all, then, next, finally", "on one hand,on the other hand","It is widely believed that...","in fact","on the contrary","in my opinion".In writing exercises, teachers can remind students to pay attention to some transitional vocabulary used in the pre-write, or for the same thing, teachers can allow students to use different words to express, usually teacher can train students guessing words skills in the teaching process and guessing the meaning of the word is actually put words on the specific context to understand.

\section{CONCLUSION}

Vocabulary. Teaching. Is a very important part in English teaching, in the vocabulary teaching, using situational yeaching method can mobilize the enthusiasm of students to learn vocabulary,so that students master consolidate and expand vocabulary,only use many ways to improve the ability of students to use vocabulary and level, we can make the student a reasonable and accurate using what they have learned vocabulary,simultaneously to conduct listening, speaking, reading, writing and other activities, verbal communication can be better achieved.

\section{INTRODUCTION OF AUTHORS}

Wang Ruiyang, female, Han, born in March 1992, master reading, research direction: English Language and Literature and American Literature

\section{REFERENCES}

[1] YANG Zhiwei.Vocational College English Teaching scenario [J].Chuzhou Vocational and Technical College,2009,02:75-76.

[2] WU Yanyan, MA Shuo.English original movie scene with English teaching [J]. Film Review, 2009,06:69.

[3] LIU Zheng.Exploration and Practice of IT and English teaching scenario [J]. Friends of Science, 2010,16:146-147.

[4] LU Jia.Multimedia teaching methods used in college English teaching scenario[J]. Maryland College of Education,2013,01:56-57.

[5] MENG Xin.On the Construction of task-based English teaching mode scenario[J].Liaoning Teachers College (Social Sciences Edition),2013,01:74-75. 